\title{
LESS COMMON PATTERNS WITH INTENSIFIERS 'TOO' AND 'VERY IN THE CORPUS OF INUGURAL ADDRESSES OF US PRESIDENTS
}

\author{
Prihantoro \\ Universitas Diponegoro \\ Address: Jl. Prof. H. Soedarto, SH, Tembalang, Semarang, \\ Jawa Tengah 50275 Indonesia \\ E-mail: prihantoro2001@yahoo.com
}

\begin{abstract}
This paper studies "very" and "too", two intensifiers used in the corpus of inaugural address of all US presidents, from Washington to Obama. My aims here is to identify uncommon pattern with "too" and "very", and the semantic prosodies as well. I downloaded the data and processed it as a corpus by using a corpus tookit called AntConc (Anthony, 2006). I used the query "very" and "too" to obtain concordances. A shared feature of these intensifiers is they mostly modify adjectives as shown by frequency. Although less significant in terms of frequency, some common patterns are discovered, such as "very $+N$ " and "very + AdjSuperlative $+N$ " construction, which are attested in COCA. One that is against prescriptive grammar is <a + too + Adj + N", where the suggested construction is usually "too $+A d j+a+N$ ". As for the semantic prosody, I found some data attested in COCA, where "too" can be used to intensify positive evaluation, which is contrary to Azar (2002) and some other grammar books. As for very, it is more flexible that the prosodies might either be positive or negative. The result of COCA and BNC has shown that these structures are uncommon. I argue that these structures are used under the markedness frame, to make listeners focus on issues that the speakers wanted to empahasize.
\end{abstract}

Keywords: very, too, intensifiers, semantic prosody, inaugural address, corpus

\begin{abstract}
Abstrak
Artikel ini menyelidiki "very" dan "too", dua pengintensif yang ditemukan dalam korpus pidato pelantikan semua presiden AS, dari Washington sampai Obama. Tujuan artikel ini adalah untuk mengidentifikasi pola tidak biasa dengan kata "very" dan "too", dan prosodi semantiknya. Saya mengunduh data pidato dan diproses sebagai korpus dengan menggunakan perangkat korpus yang disebut AntConc (Anthony, 2006). Saya menggunakan query "very" dan "too" untuk mendapatkan konkordansi. Fitur yang ditemukan dari kedua pengintensif ini adalah keduanya kebanyakan memodifikasi kata sifat seperti yang ditunjukkan
\end{abstract}


oleh frekuensi. Meskipun kurang signifikan dalam hal frekuensi, beberapa pola umum ditemukan, seperti konstruksi "very+ $N$ " dan "too+ AdjSuperlatif $+N^{\prime \prime}$, yang dibuktikan dalam COCA. Salah satu fitur yang bersebrangan dengan tata bahasa preskriptif adalah pola " $a+$ too+ Adj $+N$ ", sementara konstruksi yang biasa dipakai adalah" too $+A d j+a+$ $N$ ". Adapun secara prosodi semantik, saya menemukan beberapa data yang dibuktikan di COCA, di mana "too" dapat juga digunakan untuk mengintensifkan penilaian positif, yang bertentangan dengan Azar (2002) dan beberapa buku tata bahasa lainnya. Sementara itu, kata "very" lebih fleksibel di mana prosodinya bisa positif atau negatif. Hasil COCA dan BNC menunjukkan bahwa struktur ini jarang ditemukan. Saya berpendapat bahwa struktur ini digunakan di bawah bingkai markedness, untuk membuat pendengar berfokus pada isu-isu yang ingin ditekankan penutur.

Kata kunci: very, too, pengintensif, prosodi semantik, pidato pelantikan, korpus

\section{INTRODUCTION}

Evaluation is a normal, frequent, and regular linguistic process. It involves judgement to an entity's color, quality, size and etc. The part of speech that is common in providing evaluations is adjectives. While the phenomenon of using adjective to provide an evaluation universal, the way it is lexicogramatically realized might be language specific.

(1) A blue gemstone

(2) Batu akik merah

Stone gem red

'red gemstone'

In English, an adjective be used to modify noun, and placed usually on the left hand side of the noun. In Indonesian, it is located on the right hand side. However, it might also be located on the right context under special circumstances. See Quick, et al (1985:149).
(3) He is the only suitable actor

(4) He is the only actor suitable

(5) $\mathrm{He}$ is the only best available person

(6) $\mathrm{He}$ is the only best person available

The license of this special construction seemed to contextual as the modification, removal here, makes the sentence sound weird. Contrast them with (7) and (8). Note also how adjectives can be intensified as in (9) to (13), focus on the boldfaced words:

(7) ?He is the actor suitable

(8) ?He is the person available

(9) This room is hot

(10) This room is so hot

(11) This room is very hot

(12) This room is really hot

(13) This room is too hot

I provide examples (9) to (13), to show how intensifiers like so, very, 
really, and too are contextually used to modify the adjective hot. Besides modifying an adjective, these intensifiers can be used to modify adverbs as well.

(14) She thought very seriously

(15) She thought too seriously

In (14) and (15), too and very are used to modify adverb(s) instead of adjective(s). these two intensifiers, very and too, will be the focus of this paper. In most grammar books used by English learners such as the more generic term adverb is usually used. It is also correct as intensifiers in English fall to this part of speech. The discussion of these intensifiers in Murphy (2004), and Azar (2002) is more on grammar rather than semantics as I have previously shown.

This study is corpus based. The use of corpus is important as it records the actual language. The findings may even contradict to artificial examples made by grammar books authors. See Real Grammar: A Corpus Based Approach to English by Biber \& Conrad (2009). One recent study by (Frej \& Nam, 2014) has indicated that the semantics of these intensifiers is also a crucial importance. They studied the use of very and too in BNC (British National Corpus) and discovered that too is used for negative polarity words or to express an irony. Very on the other side is fairly neutral.
Before taking Frej and Nam's research into account, let us validate this by another corpus, British National Corpus $^{1}$ (BNC). BNC is a corpus where the data is collected from speakers of British English. Now, let us compare this with COCA ${ }^{2}$ (Corpus of Contemporary American English). COCA is claimed to be the largest English reference corpus (Davies, 2008) in terms of data size. 
Figure 1. Top Ten of $\langle$ too $\rangle\langle A\rangle$ in COCA

\begin{tabular}{|c|c|}
\hline 1ULLA $=$ & $1 / 8=$ \\
\hline TOO BAD & $332=$ \\
\hline TOO DIG & 3107 \\
\hline IUW SM/ $\perp$ & 3011 \\
\hline$T O D$ Y $N$ NG & $27 \pi t$ \\
\hline TOC BUEY & 25?: \\
\hline TCO HIISH & 2523 \\
\hline Th ח ח & 2253 \\
\hline 100 GOUU & $21 /=$ \\
\hline TOO EARLY & 2043 \\
\hline
\end{tabular}

Figure 2. Top Ten $<$ very $><A>$ in COCA

\begin{tabular}{|c|c|}
\hline VLR' GOOD & 17502 \\
\hline VERY :NPORTANTT & 11730 \\
\hline VERY UARHLUL & 3828 \\
\hline VIRV CITTERENT & 3629 \\
\hline WERY HARD & 4935 \\
\hline VER' CLUSE & 1616 \\
\hline VIR GTRONG & $452 C$ \\
\hline VER $\mathrm{HIIBH}$ & 4357 \\
\hline VLEN SMRLL & 1226 \\
\hline VIR CLLAR & 4007 \\
\hline
\end{tabular}

\section{METHOD}

In this research, I will focus on the collection of Inaugural Addresses of US President from the first president, George Washington, to the current president, Barrack Obama. Inaugural address is carefully arranged, not just an impromptu address. These days, presidents have their own speech writer. As for US presidents, the presence of speech writer is obvious, and no longer a secret (Ritter \& Medhurt, 2003). Another reason for the preference of this data is its wide range. The range of presidents' inaugural address from the first to the recent president allows us to observe how language may change (if any). This present study is aimed to identify it, and if it holds true, to what extent.

I began this research by collecting the digital texts where the format was (.pdf) readable by acrobat reader or similar software. The format of the text is converted to (.txt). Each file represents one inaugural address. When the president is reelected, a new addresses, in addition to his previous address, will be made. For this reason, each file is named with year and the last name of the president for instance 2009_Obama, and 2013_Obama. These are examples when one president is reelected. These multiple files were 
processed with AntConc, a corpus toolkit (Anthony, 2006).

The intensifiers were used as keywords to retrieve its occurrence. The result of the retrieval was visualized by concordance; where keywords are surrounded by their left and right contexts. Phrases containing the intensifiers are the raw finding of this research. Each of them was carefully examined; common patterns were removed. Uncommon structures are kept for further consultation with reference corpora: BNC, COCA, and COHA. COHA is Corpus of Historical American English. It is necessary to consult this historical corpus to identify whether the structure was common at some point of time in the past. This will test whether Frej and Nam's (2014) finding in BNC about semantic prosody of too and very is also attested in this corpus.

\section{RESULTS AND DISCUSSION}

Very

The adjective modified by the intensifier is usually is its normal state; meaning that it is not being compared. I however, found a counter example to this, where a superlative adjective may accompany very:

(1) of what the very lowest standards of today call

In the example I've discovered, an intensifier <very> modifies <lowest> a superlative form of $\langle$ low $\rangle$. The superlative form here is uncommon; its occurrence might be attested in a large corpus but insignificant as compared to <very + A> pattern. Compare the occurrence of <very + Asuprl> two large English corpora: BNC and COCA. Metasymbol [ $\left.\mathrm{j}^{*}\right]$ indicates adjective and [jjt*] indicates superlative adjective. The core expression is accompanied by article [at*] and noun [nn*] on the left and right hand sides respectively. Right besides the noun, a metasymbol -*ing is added, because the interface seems to consider present participle verbs to be noun. The metasymbol is used to negate the -ing form. Therefore, it will retrieve all nouns that are not -ing form

Table 1. Comparing <very > <A> and <very $><$ Asuprl $>$ in BNC and COCA

\begin{tabular}{lll}
\hline & Query & \\
\cline { 2 - 3 } & Adj $=>$ [at] very [j*]-*ing. [nn*] & $\begin{array}{l}\text { Superlative Adj => [at] very [jjt*]- } \\
\text { *ing. [nn*] }\end{array}$ \\
\hline COCA & 70217 & 935 \\
\hline BNC & 17164 & 331 \\
\hline
\end{tabular}


In BNC and COCA, the result of the retrieval shows that the frequency of the pattern is not significant, less than $6 \%$ in COCA and $4 \%$ in COCA as compared to normal adjective form.
The pattern is still in use, but not common. Table 2 shows the frequency of occurrence of such pattern in $\mathrm{COHA}$ (Corpus of Historically American English):

Table 2. Frequency of Occurrence of $\langle\mathrm{a}+$ very $+\operatorname{Adj}|$ Asuprl $+\mathrm{N}\rangle$

\begin{tabular}{|c|c|c|}
\hline \multirow[t]{2}{*}{ Year } & \multicolumn{2}{|r|}{ Frequency } \\
\hline & $\begin{aligned} \text { Adj }= & >[\text { at* }] \text { very }\left[\mathrm{j}^{*}\right]- \\
& * \text { ing. }[\mathrm{nn} *]\end{aligned}$ & $\begin{array}{c}\text { Superlative Adj }=>\left[\text { at*] very }\left[\mathrm{jjt}^{*}\right]\right. \\
\text { *ing. [nn*] }\end{array}$ \\
\hline 1810's & 173 & 5 \\
\hline 1820's & 1239 & 28 \\
\hline 1830 's & 2818 & 121 \\
\hline 1840 's & 3379 & 158 \\
\hline 1850's & 3808 & 161 \\
\hline 1860 's & 3469 & 160 \\
\hline 1870's & 4278 & 204 \\
\hline 1880 's & 4526 & 193 \\
\hline 1890 's & 4405 & 197 \\
\hline 1900 's & 3644 & 160 \\
\hline 1910's & 3462 & 174 \\
\hline 1920 's & 3573 & 147 \\
\hline 1930's & 3005 & 92 \\
\hline 1940's & 2803 & 63 \\
\hline 1950's & 2626 & 62 \\
\hline 1960 's & 2707 & 59 \\
\hline 1970's & 2777 & 42 \\
\hline 1980's & 2541 & 51 \\
\hline 1990's & 2564 & 49 \\
\hline 2000's & 2654 & 58 \\
\hline
\end{tabular}

I refer to COHA as it makes possible for the engine to show how the frequency of occurrence of the two structures changes over time. It is interesting that the two structures are consistent in terms of that pattern that uses superlative adjective is always much lower in frequency (below 5\%). See the comparison of axis $\mathrm{X}$ in figure one (Adj) and two (superlative Adj), where the pattern that includes superlative adjective is 250 max, which is $\quad 5 \%$ from 5000 . 
Figure 3. Adj Vs Superlative Adj in 〈a + very + Adj $\mid$ Asuprl + N>

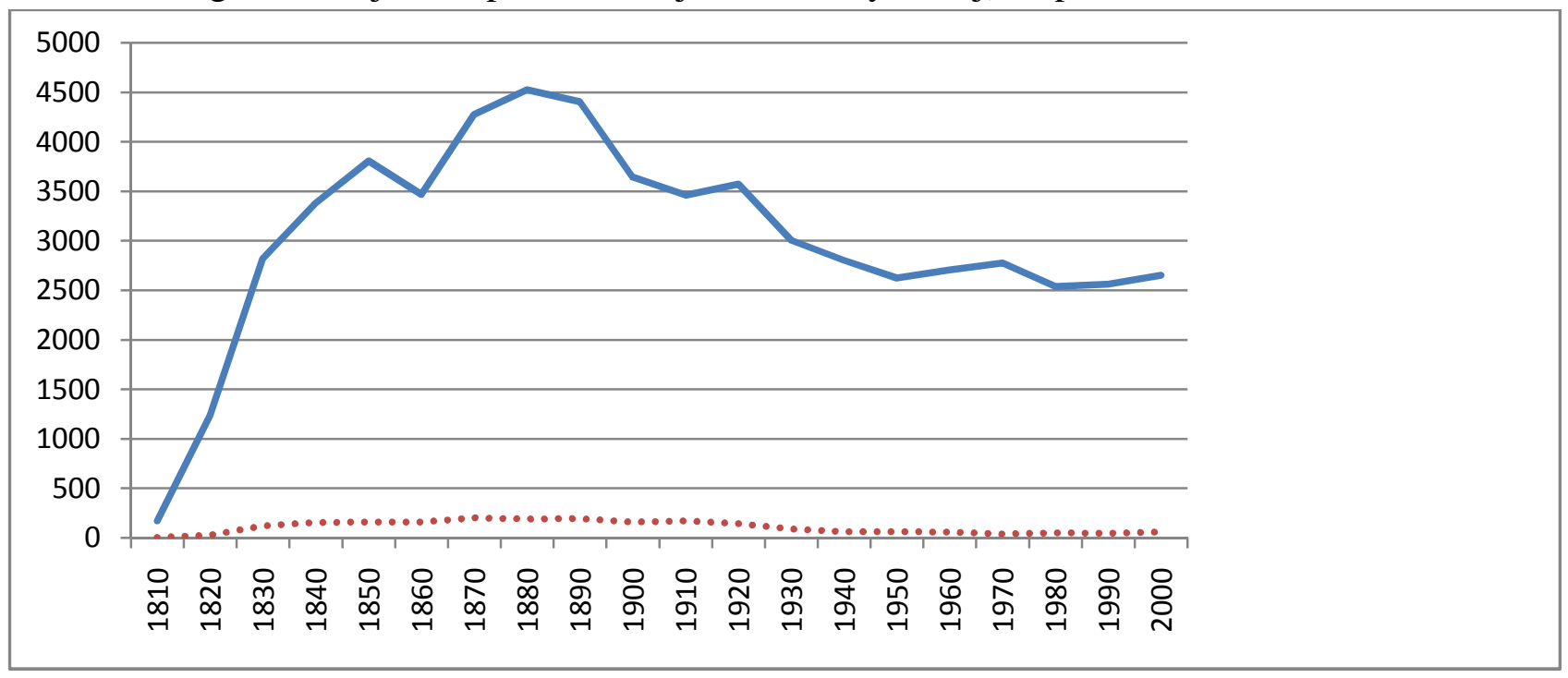

The normal line indicates the first pattern where normal adjective is used, while dotted line indicates the pattern where superlative adjective is used. The trend of use of the two patterns, seems to improve sharply since 1810, and reached its peak in 1870 (Adj)/1880(Superlative Adj). The pattern that includes superlative adjective, however, dropped sharply since then, and began to stabilize since 1940. The drop was also experienced by the pattern that includes simple adjective, but the drop is not as sharp as the superlative adjective. It is stable since 1950. What might interest historical linguists here is that, the first pattern seems to follow the second one in a decade either the improvement or the drop. We can see how the superlative adjective pattern reached its peak in 1870, and a decade after that, the simple adjective pattern also reached its peak. The same goes for the stabilization after the drop, which is 1940 for the superlative adjective pattern and 1950 for the simple adjective pattern.

Figure 4. Concordance Plot of 'the very lowest standards' HIT FILE: 38 FILE: 1937-Roosevelt.txt

\begin{tabular}{|l|l|}
\hline & \\
\hline
\end{tabular}

No. of Hits $=1$ File Length (in chars) $=10607$
There are three possibilities about why such pattern(s) are used. First, the speaker was being inaccurate at that time, which I believe was least likely to happen. An inaugural address is a formal address and only spoken only one time during their presidential term. The second one is the representation of the language at that time. This is a bit historical, but I have 
reasons to believe that this is not the case as its comparison with its common structure showed that the structure is less commonly used. The most possible factor is the third one; a marking. Here, marking is performed grammatically on the surface form, but the aim is to focus the listeners. In 'the very lowest standards' President Roosevelt wanted to how serious the problem was at that period.

But here is the challenge to our democracy: In this nation I see tens of millions of its citizens -a substantial part of its whole population -- who at this very moment are denied the greater part of what the very lowest standards of today call the necessities of life.

I see millions of families trying to live on incomes so meager that the pall of family disaster hangs over them day by day.

I see millions whose daily lives in city and on farm continue under conditions labeled indecent by a so-called polite society half a century ago.

I see millions denied education, recreation, and the opportunity to better their lot and the lot of their children.

I see millions lacking the means to buy the products of farm and factory and by their poverty denying work and productiveness to many other millions.
I see one-third of a nation illhoused, ill-clad, ill-nourished.

My argument that the use of such pattern is to mark emphasis grounds on the following analysis. The head of the pattern is <standards >. By saying <standards>, President Roosevelt here referred to the necessities of life, where even the minimum standards could not be met; which is an irony. Roosevelt even made it clear with <I see millions> rhyming on the examples he commented. Some negative polarity words are used such as 'meager' to modify 'income', 'indecent' to refer to 'condition', 'deny' where the themes are education, recreation and opportunity', 'poverty', and 'ill' rhymed phrases/hyphenated compound as in 'ill-housed, ill-clad, and ill-nourished'.

Too

Attributive Vs Predicative Adjective Modified by <too>

In the texts that I research in this study, the patterns where too modify attributive adjectives occur:

(2) committed from a too hasty enactment. $\{S\} \quad$ There is (Harrison, 1841)

In each example, the adjectives modifies noun attributively with article in (x) and without article in (x). When article is used, the noun is singular and when the article is not used, the noun is plural. In most grammar books, <too> is described as an intensifier for 
adjectives in predicative position as in Quick, Greenbaum, Leech, \& Starvick (1985), Azar (2002) and Murphy (2004). It goes parallell to examples provided in several standard english dictionaries under the lemma $\langle$ too>. In COCA and BNC. Let us see the collocates on the left and right handsides of $\langle$ too $+\mathrm{Adj}\rangle$ pattern:

Table 3. Left and Right context of <too + Adj>

\begin{tabular}{llllllll}
\hline Left & \multicolumn{7}{c}{ Right } \\
\hline be & 5724 & far & 128 & to & 7440 & that & 89 \\
\hline not & 579 & getting & 127 & . & 3547 & future & 67 \\
\hline almost & 185 & little & 92 & for & 1253 & of & 64 \\
\hline already & 180 & only & 77 & , & 996 & & \\
\hline never & 178 & put & 76 & WITH & 97 & & \\
\hline
\end{tabular}

Of 100 results, the above table provides strongest collocates to left and right handside. Pattern It seems that the left handside more varies, as it actually gave more than 10 collocates. As for the right handside, it is the opposite. The top 100 resulted in less than 10 collocates, and two of them are punctuations. This describes that <too + Adj> pattern is more commonly used in clause/sentence final position. None of the left or right handside context From frequent words sorrounding the core expression, pattern $<$ be + too + Adj + to $>$ and $\langle$ be + too + for $+\mathrm{N}>$ seem to be semi-fixed. First pattern was also explicitly found in the reference grammar by Murphy (2004), while the second one is in Azar (2002).

The collocates of the left hand side do not give any indication that <too + Adj> function attributively. Among strong collocates on the left none of them are articles, which is one indication of noun phrase modifier. This is confirmed by the right hand side collocates. The strong collocates on the right hand side of the core is <to $\rangle$, $<$ for $>$, and <with>. Longman Dictionary of English, in its composition hints, clearly forbids the use of <too> to modify adjectives in attributive position. And recommend another structure:

"do not use too after 'a' and before an adjective and noun. Put too and the adjective before ' $a$ '.

It forbids pattern $<\mathrm{a}$ too $+\mathrm{adj}$ $+\mathrm{N}>$ and suggests that pattern <too + $\operatorname{Adj}+\mathrm{a}+\mathrm{N}>$. Therefore, instead of ' $\mathrm{a}$ too high price', the form 'too high a price' is recommended. This is confirmed by the frequency comparison of these two patterns in COCA and BNC. A comparison of these two structure in COHA also shows that pattern $\langle$ article + too $+\mathrm{Adj}+\mathrm{N}\rangle$ is less common in English as compared to its counterpart $\langle$ too + Adj + Article $+\mathrm{N}\rangle$, and the trend is getting lower and lower from year to year: 
Table 4. Comparing <too + Adj + Article $+\mathrm{N}\rangle$ and $\langle$ article + too + Adj $+\mathrm{N}\rangle$ in BNC and COCA

\begin{tabular}{lll}
\hline & $\begin{array}{c}\text { too [j*] [at*]- } \\
\text { *ing. [nn*] }\end{array}$ & $\begin{array}{c}\text { [at*] too [j*]- } \\
\text { *ing. [nn*] }\end{array}$ \\
\hline COCA & 2408 & 112 \\
\hline BNC & 812 & 74 \\
\hline
\end{tabular}

Table 5. Comparing $<$ too + Adj + Article $+\mathrm{N}>$ and $\langle$ article + too + Adj $+\mathrm{N}>$ in COHA

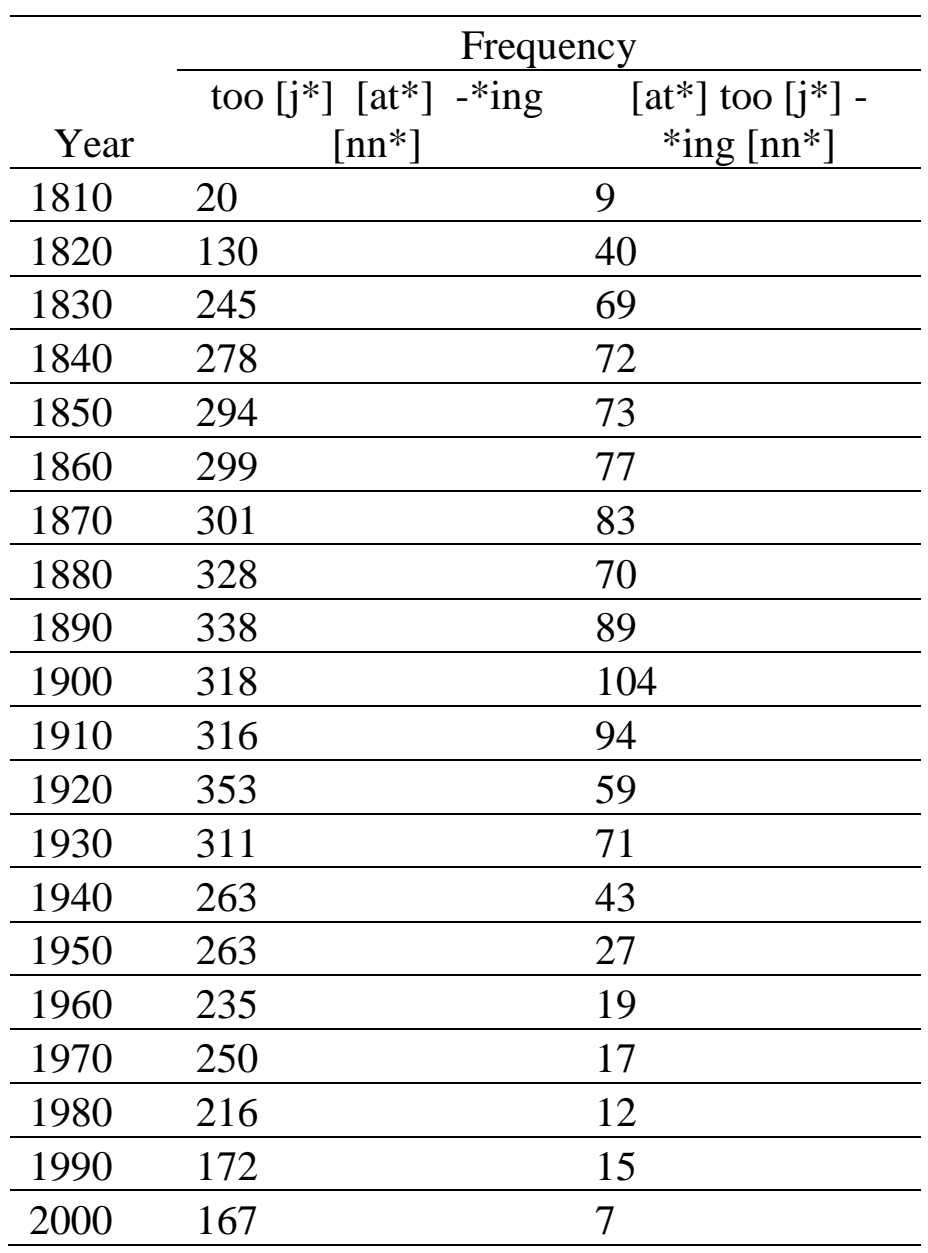

The trend for the two patterns is almost the same. The number steadily improved from 1810 and reached their peaks at 1890-1900. But since then, the use of these patterns are getting less and less common. The consistency can also be seen in the frequency where <article + too $+\mathrm{Adj}+\mathrm{N}>$ is always much lower than $<$ too + Adj + Article $+\mathrm{N}>$. 
Figure 5. The comparison of $\langle$ article + too $+\mathrm{Adj}+\mathrm{N}\rangle$ and $\langle$ too + Adj + Article $+\mathrm{N}\rangle$

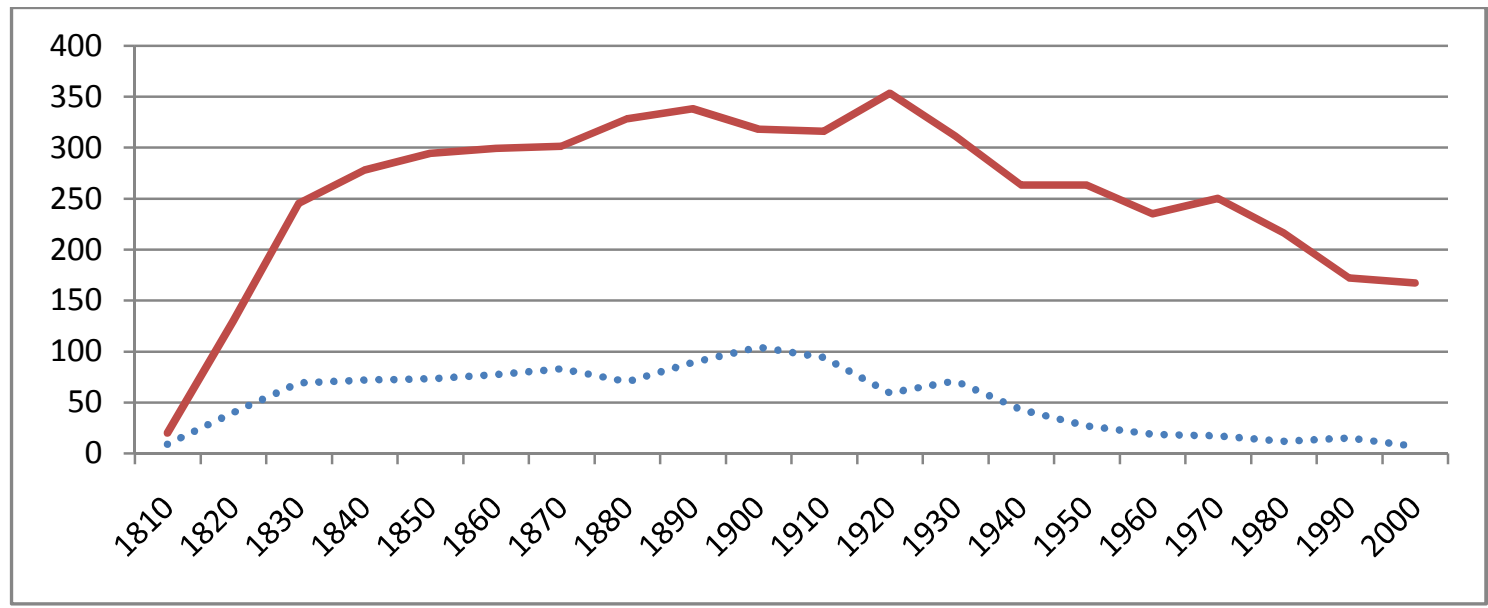

(1) done without imposing

$\underline{\text { too heavy burdens }}$ on their citizens $\quad$ (Polk, 1845)

Another pattern is $<$ too + Adj + $\mathrm{Npl}>$ without any article. This is also uncommon pattern and against grammar rules. But first, we have to confirm that this pattern does exist in English. A retrieval by too [j*] $\left[\mathrm{nn}^{*}\right]$ query will mostly includes article at $\mathrm{N}$ -
1 context. Therefore, I modified the query by adding negated article - too [j*] $[\mathrm{nn} *]$, which means that it will retrieve all words at $\mathrm{N}-1$ of the core expression which is not an article. We will compare now how this pattern applies

Table 6. Pattern -[at*] too [j*] [nn*] in COCA and BNC

\begin{tabular}{|c|c|c|}
\hline \multirow[t]{2}{*}{ Year } & \multicolumn{2}{|c|}{ Frequency } \\
\hline & $\begin{array}{c}-\left[\text { at*] too }\left[j^{*}\right]-* \text { ing }\right. \\
{\left[n n 1^{*}\right]}\end{array}$ & -[at*] too $\left[j^{*}\right]-*$ ing $[\mathrm{nn} 2 *]$ \\
\hline COCA & 1189 & 214 \\
\hline $\mathrm{BNC}$ & 372 & 98 \\
\hline
\end{tabular}

The retrieval resulted on 214 hits on COCA and 98 hits on BNC, which are more than the pattern where an article precedes (see table 4 where it shows only 112 hits found on COCA and 74 hits on BNC). We will see how it appears in COHA: 
Table 7. Comparing <too + Adj + Nsing > and $<$ too + Adj + Nplural $>$ in COHA

\begin{tabular}{lll}
\hline \multirow{2}{*}{ Year } & \multicolumn{2}{c}{ Frequency } \\
\cline { 2 - 3 } & $-\left[\mathrm{at}^{*}\right]$ too $\left[\mathrm{j}^{*}\right]-$ *ing $_{\left[\mathrm{nn} 1^{*}\right]}$ & $-\left[\mathrm{at}{ }^{*}\right]$ too $\left[\mathrm{j}^{*}\right]-*$ ing $\left[\mathrm{nn} 2^{*}\right]$ \\
\hline 1810 & 24 & 5 \\
\hline 1820 & 55 & 19 \\
\hline 1830 & 112 & 43 \\
\hline 1840 & 131 & 49 \\
\hline 1850 & 145 & 39 \\
\hline 1860 & 153 & 54 \\
\hline 1870 & 157 & 43 \\
\hline 1880 & 167 & 51 \\
\hline 1890 & 151 & 63 \\
\hline 1900 & 193 & 69 \\
\hline 1910 & 191 & 74 \\
\hline 1920 & 194 & 67 \\
\hline 1930 & 192 & 64 \\
\hline 1940 & 179 & 59 \\
\hline 1950 & 168 & 33 \\
\hline 1960 & 126 & 36 \\
\hline 1970 & 101 & 30 \\
\hline 1980 & 99 & 24 \\
\hline 1990 & 81 & 13 \\
\hline 2000 & 91 & 8 \\
\hline
\end{tabular}

COCA provides many metadata allows COCA users to retrieve functional ways on visualizing the the source of the text, in this case the results on the retrievals. Concordance is domain. From five domains in COCA, of course a must, but one that is these uncommon structures are found to extremely helpful is the domain have high frequency on spoken and visualization. The support from its fiction.

Table 8. Distribution across Domains in COCA

\begin{tabular}{lllllll}
\hline & \multicolumn{5}{c}{ Rank } \\
\cline { 3 - 6 } & & SPOKEN & FICTION & MAGAZINE & NEWSPAPER & ACADEMIC \\
\hline 1 & $\begin{array}{l}\text { [at*] very [j*] } \\
\text { *ing.[nn*] } \\
\text { a very low standard }\end{array}$ & $1<=$ & 5 & 4 & 3 & 2 \\
\hline 2 & $\begin{array}{l}\text { [at*] very [jjt*] - } \\
\text { *ing.[nn*] } \\
\text { the very lowest } \\
\text { standards }\end{array}$ & 4 & 2 & 5 & 3 \\
\hline 3 & $\begin{array}{l}\text { too [j*] [at*]-*ing. } \\
\text { [nn*] } \\
\text { too hasty an } \\
\text { enactment }\end{array}$ & $1<=$ & 2 & & \\
\hline
\end{tabular}




\begin{tabular}{llllll}
\hline 4 & $\begin{array}{l}\text { [at*] too [j*] }-4 \\
\text { *ing.[nn] } \\
\text { a too hasty } \\
\text { enactment }\end{array}$ & $1<=$ & 3 & 5 & 2 \\
\hline 5 & $\begin{array}{l}\text {-[at*] too [j*] } \\
\text { *ing.[nn1*] } \\
\text { too heavy burden }\end{array}$ & $1<=$ & 2 & 4 & 3 \\
\hline 6 & $\begin{array}{l}\text {-[at*] too [j*] - 4 } \\
\text { *ing.[nn2*] } \\
\text { too heavy burdens }\end{array}$ & $1<=$ & 2 & 5 & 3 \\
\hline
\end{tabular}

I do believe that the uncommon structures were selected with careful consideration. The object itself is spoken language. It is however no ordinary spoken data. Inaugural address of a president is too important to deliver without preparation. Even these days, some presidents elect have already their own speech writer instead of delivering it impromptu.

The concept of markedness here is a crucial importance; what is marked and unmarked. It actually began with Trubetzkoi's proposal in describing phonology (Trubetzkoy, 1931), but became widespread to other disciplines, including grammar or syntax (Croft, 2003). What we have seen here is the preference for uncommon structures with a purpose. Structures that are less dominant were preferred to attract listeners to focus on the issues being delivered. This is analogous to orthographical marking such as boldfaced fonts, italic fonts, or all uppercase fonts that 'force' readers to put their attentions on the marked elements.

\section{CONCLUSION}

This paper has described how two intensifiers very and too used to modify adjectives and noun in the corpus of US presidents inaugural address from the first to the current US president. It has managed to retrieve uncommon structures, where in these structures, the adjective takes superlative form. As for too there is a structure where it takes predicative form instead of the common attributive form. My findings here are justified by the Corpus of Contemporary American English (COCA): one of the largest and freely accessible English corpora. I also compare the finding to British National Corpus (BNC); the result of the retrieval from these corpora is parallel to my finding that these structures are uncommon. By observing its frequency of occurrence historically, I manage to conclude that they are used less and less. Reason why these structures were used is as a marking. I avoid the presumption that it is merely errors made by speakers on rapid speech under their consciousness. The speakers, on the opposite, were fully conscious and selected these structures deliberately as they want to emphasize on serious issue. Some part of this study somehow justify the finding of Frej \& Nam (2014), where too has the sentiment to modify adjective with negative quality. All of the issues emphasized by too in these uncommon structures are negative. 


\section{ACKNOWLEDGMENTS}

I would like to extend my gratitude to those who have helped the whole process of writing this article.

\section{REFERENCES}

Aerim, A., Laporte, E., \& Jeesun, N. (2010). Semantic Polarity of Adjectival Predicates in Online Reviews. Seoul International Conference in Linguistics (pp. 20-27). Seoul: Korea Linguistic Society.

Anthony, L. (2006). Concordancing with AntConc: An introduction to tools and techniques in corpus linguistics. JACET Newsletter, 155-185.

Azar, B. S. (2002). Understanding and Using English Grammar 3rd Edition. New York: Longman.

Biber, D., \& Conrad, S. (2009). Real Grammar: A Corpus Based Approach to English. New York: Longman Publishers.

Chomsky, N. (1957). Syntactic Structure. New York: Mouton De Hague.

Croft, W. (2003). Typology and Universals. Cambridge: Cambridge University Press.

Davies, M. (2008). American Corpus. Retrieved August 9, 2014, from The corpus of contemporary
American English (COCA): http://www.americancorpus.org

Frej, Y., \& Nam, J. (2014). Study on the Sentiment Polarity Types of Collocations for too and very. Journal of Philology (1), 23-32.

Greenbaum, S. (1970). Verb Intensifier in English. New York: Intensifier.

Gross, M. (1997). The Construction of Local Grammars. In E. Roche, \& Y. Schabes, Finite State Language Processing (pp. 329354). Massachusetts: MIT Press.

Murphy, R. (2004). English Grammar in Use 3rd Edition. Cambridge: Cambridge University Press.

Paumier, S. (2008). Unitex Manual. Paris: Universite Paris Est Marne La Valee \& LADL.

Quick, R., Greenbaum, S., Leech, G., \& Starvick, J. (1985). A Comprehensive English Grammar. London and New York: Longman.

Ritter, K., \& Medhurt, M. (2003). Presidential Speech Writing. Texas: Texas University Press.

Trubetzkoy, N. (1931). Die phonologischen systeme. Travaux du Cercle linguistique de Prague, 4, 96-116.

\section{NOTES:}

\footnotetext{
${ }^{1} \mathrm{http} / / / \mathrm{www}$. natcorp.ox.ac.uk/

${ }^{2}$ http://corpus.byu.edu/coca/
} 